\title{
THE INHERENT RIGHT TO MAKE A MISTAKE (ON INFORMED CONSENT)
}

\section{Zorin NA $\otimes$}

Russian Society for Evidence Based Medicine, Moscow, Russia

\begin{abstract}
The Informed Consent (IC) procedure is considered as a legal construct, a product of liberal economics. As such, IC is a tool for shifting responsibility for the choice of intervention from the seller of health care services to the consumer and is a binding contract to avoid legal liability and all sorts of losses on both sides. The set of problems surrounding the IC can be explained by the significant difference between an experimental procedure (for which it was originally created) and everyday clinical practice. The application of the IC law has no mechanisms for its individual application because it fails to take into account the psychology of decision-making. Keywords: bioethics, informed consent, industrial development of medicine, liberal economics, psychology of decision-making.
\end{abstract}

Keywords: bioethics, voluntary informed consent (VIC), industrial development of medicine, liberal economics, decision-making psychology

$\triangle$ Correspondence should be addressed: Nikita A. Zorin

Dmitrovskoe highway, 46, b. 2, of. 17, Moscow, 127238; nzorin@inbox.ru

Received: 16.03.2021 Accepted: 26.03.2021 Published online: 29.03.2021

DOI: 10.24075/medet.2021.004

\section{НЕОТЪЕМЛЕМОЕ ПРАВО СОВЕРШИТЬ ОШИБКУ (ОБ ИНФОРМИРОВАННОМ СОГЛАСИИ)}

\author{
Н. А. Зорин $\bowtie$ \\ Общество специалистов доказательной медицины (ОсДМ), г. Москва, Россия
}

\begin{abstract}
Рассматривается процедура добровольного информированного согласия (ДИС), как правовая конструкция, продукт либеральной экономики. В этом качестве ДИС является инструментом перекладывания ответственности за выбор вмешательства с продавца медицинских услуг на потребителя и является контрактным договором, позволяющим избежать судебной ответственности и всевозможных потерь с обеих сторон. Комплекс проблем вокруг ДИС можно объяснить существенным различием ситуации эксперимента (для которой оно создавалось первоначально) и повседневной клинической практики. Закон о ДИС не имеет механизмов индивидуального применения, ибо не учитывает вопросов психологии принятия решений.
\end{abstract}

Ключевые слова: биоэтика, добровольное информированное согласие (ДиС), индустриальное развитие медицины, либеральная экономика, психология принятия решений

$\triangle$ Для корреспонденции: Зорин Никита Александрович

Дмитровское шоссе, д 46 к 2, оф 17, г Москва, 127238; nzorin@inbox.ru

Статья получена: 16.03.2021 Статья принята к печати: 26.03.2021 Опубликована онлайн: 29.03.2021

DOI: $10.24075 /$ medet.2021.004

"...Securing agreement on general claims (like "respect human beings") is easy but securing agreement on the meaning of these claims is not".

Xavier Symons [1]

\section{Background $^{1}$}

The informed consent (IC) is justly regarded as an achievement in social development that has been established during transition from "medical" to "social" model of medicine. PD Tishhenko writes the following: "In the space, open to the public eye, the idea of human rights as the attribute of individual's unique personality and citizenship is beginning to dominate, the implementation of which in biomedicine shows up in the fact, that the main principle concerning the doctor-patient relationship is the principle of voluntary informed consent. Moreover, this concerns both scientific research and daily medical practice" [2]. However, the further development has demonstrated significant differences between the experimental procedure (for which the subjects' IC was originally created and used $)^{2}$ and the daily clinical practice, whereas there has been no substantive change in $\mathrm{IC}^{3}$.

A notable difference between the subject's "problem of choice" and the patient's choice is the fact that the choice of participation/non-participation (in the experiment) is joined by the treatment option selection, which is most commonly the selection not between two options, but between multiple options. Moreover, the patient is cornered by the disease; refusal to make a decision or fear of "bad decision" inevitably gives rise to the feeling of guilt and does not contribute to recovery. This distinction was the reason for mutual irritation of physicians and patients (specifically in Russia). They started living in a world, where the statement "What gave you the right to tell me about it?", attributed to Z. Freud, who was told by his physician that he had cancer, was replaced by the nearly forcible knowledge about the disorder ${ }^{4}$. After all, biopower (M. Foucault) then "took the form of caring about the quality of human life, its health and effectiveness" [2].

Where does the conflict come from? This would be the focus of our report.

\section{Ethics and market economy}

Apparently, the Nuremberg Code moral and legal standards, just like the subsequent Declaration of Helsinki, that gave rise to contemporary IC used in daily clinical practice, were successfully seized by the Market, and IC was absorbed in the industrial, market-oriented, and economic environment serving the interests of those.

IC has nothing to do with medicine. It is a legal construct, the product of market economy that includes medicine as a health care services production industry. It is a product of a contractual arrangement between the seller and the consumer 
of services, and, in many ways, a consequence of judicial precedents. At times of complete and utter mind games, overwhelming mutual blackmail and clarification of claims in court, the existence of $\mathrm{IC}$ is reasonable and necessary.

The objective of IC is to allow both parties to avoid judicial responsibility and to deter all kinds of losses. The origin of IC is market (economy). IC is a legal structure. This is indirectly confirmed by the fact, that the ideas of IC are actively promoted either by non-physicians, or by those, who have not requested any consent from the patient for a long time... The mechanism for IC creation is convention, the process agreement "sanctified" by the actions making it lawful: for example, by "internationality" (i.e., the global segregation), and "collectivization" of guilt and liability.

Everything else (discussions about "rights", "freedom", etc.) has turned into political and ideological "noise", which allows a certain range of people to use the listed mechanisms to control the actions of others [3]. In her article "How Neoliberalism Is Damaging Your Mental Health", Ruth Cain (lecturer in law, University of Kent) tells of "an economy of non-stop distraction, in which attention is repeatedly grabbed at and financially exploited" [4].

There are various mechanisms of finger-pointing and shifting the responsibility as a form of protection against judicial responsibility (consequences of harsh actions, accidents and occasions) both in medicine and in other areas related to contractual arrangements:

- IC

- Conflict of interest disclosure

- Assisted suicide ("risk mutualization")

- Writing prescription containing just the international nonproprietary name (the patient can select an affordable drug)

- Warning about potential health hazard of harmful addictions (smoking, alcohol consumption, etc.)

- Warning about unacceptability of certain actions (about washing a dog in a washing machine, drying a cat in a microwave, the possibility to burn one's hands with hot coffee in a paper cup, and other "instructions for imbecile"; almost all of them result from judicial precedents) [5].

These mechanisms work even in the realm of outright fraud: after his release from prison, SP Mavrodi gave us a "groundbreaking" warning: "Be careful! It's a pyramid scheme!"... I.e., he gave a clear warning, telling the public he was a thief! And then? And then it's our fault that we have agreed to participate after such a warning... [ibid.]

The closest thing to $\mathrm{IC}$ is the customer's decision to purchase or not to purchase a product after the seller has told him straight all the pros and cons of the product.

Therefore, the majority of Russian physicians do not like the IC requirements. These destroy the physician's identity. The physician ceases to be "hippocratic": the one, who has been formerly responsible for intervention decision making, becomes a service worker. Ultimately, the physician cares only about the stakeholders' signatures on the IC agreement.

The concept of having "a right to be informed" is put above the concept of benefit and harm. The patient has a right to make a wrong choice (not to choose, as it is called, the most optimal option), and the physician has to bend before this right contrary to his original intent (to "nonmaleficence" and other "old-fashioned" virtues of classical medicine)... Unless the patient selects the "option" not to be informed, prohibition to push the patient for decision paradoxically deprives the physician his right to give a qualified advice, and forces the physician to play sort of a game with the patient, similar to "yes and no not to speak", "black and white not to take...".

The liberal colleague writes the following: "When informing the patient, we have to consider the fact that it is not us who make a treatment decision, but the patient. Moreover, it is extremely important to keep in mind that the decision to be treated or not to be treated, as well as the treatment option selection, is not at all a medical decision" [6].

In terms of classical medicine, it sounds like sacrilege. All right, the patient's decision to be treated/not to be treated is really not a medical decision ${ }^{5}$. However, why do we consider the decision non-medical when shifting the responsibility to select the treatment option onto patient? Because shifting the responsibility to make a medical decision onto incompetent person requires "legal cleanup" to avoid judicial responsibility for such shifting. And then the treatment method (!) becomes the "non-medical" issue.

Within the bounds of "old-fashioned" classical "hippocratic" medicine, the principles of which are being taught at the medical higher education institutions by inertia along with the IC principles, shifting the responsibility onto patient is considered immoral. There is a "cognitive dissonance". Therefore, the opposite process aimed at removing the conflict is going on. The "tenets" of classical medicine (Hippocratic Oath, etc.) are revised, rethought and destroyed in a logical manner, being considered as outdated [7], [8].

The concept of morality is also being revised; it can transform into its opposite in accordance with economic viability. It is something like the Xth revision of Ten Commandments [3].

The Sicily statement for some reason firmly tied "the round and the sour", and namely IC and evidence-based medicine (EBM). The statement stipulates: "Decisions should be made by those receiving care, informed by the tacit and explicit knowledge of those providing care, within the context of available resources» [9]. This link (IC=EBM) appears to be a discouraging political chicanery, very much like the link between homophobia and fascism. This paralyzes any criticism. Who wants to be perceived as being a retrograde or a rascal?

In the context of modern economic liberalism of medicine the responsibility not only of the intervention selection, but also of his health, has been shifted onto patient under the pretext of Freedom (Free will). "Neoliberalised healthcare requires every patient $<\ldots . .>$ to take responsibility for her own state or behaviour. $<\ldots>$ Neoliberal states divest themselves of the costs of care by individualising and privatising care duties. People displaying troubling symptoms are divided into the "dangerous", against whom punitive or authoritarian containment methods may be used, and those left to cope with what resources they or their families have left" [4].

\footnotetext{
${ }^{1}$ All the emphasis marks to the text are made by me, NZ, unless explicitly stated otherwise.

2 "First of all, the subject informed consent is essential, which means that the person engaged in the experiment has a legitimate right to give such consent and is free to choose, without any violence, deception, fraud, trickery, or any other forms of covert coercion; has adequate knowlege allowing him/her to grasp the experimental concept and to make an informed decision. The latter requires the subject to be informed about the nature, duration and objective of the experiment; experimental methods; all possible inconvenience and risks; the consequences of the experiment for the health and moral well-being before submitting the consent". [ibid.]

${ }^{3}$ Another variant of such mismatch is the use of IC to euthanasia. However, the details of the issue fall outside the scope of our study.

${ }^{4}$ One female patient said: "I was offered to submit IC; after a conversation I felt like I had been molested" (private message to NZ). Yes, the patient has a right to refuse to be informed and to choose. However, this right is usually realized after conversation with the physician

${ }^{5}$ By the way, regardless of the "freedom", W Vlasov does not like such a choice: "Unfortunately, the wretched Russian law provides for "consent to intervention" and "refusal to intervention". Thus, the patient is forced into synthetic situation of choosing between treatment and no treatment. The fact in concealed (?NZ) that consent submission is a form of treatment option selection, which is provided for by the law, pointing out the necessity to inform the patient about "other treatment options". (?NZ) [lbid.].
} 
Actually, unless someone is unaware, real patients (in case of no serious life threat) are being affected by various illnesses and use the treatment options as they see fit [10].

And now, let's imagine the impossible. There lives an intelligent, conscientious and honest physician, who "has the knowledge about all the proposed interventions", even the knowledge no one else has (i.e. knowledge about the COVID vaccines). He has no unconscious mind, but only conscious awareness. Perhaps, he may also have a natural skill to talk to other people in a way that his words are understood by every person (regardless of daily learning of lessons that all people do is fail to understand each other...). There also lives an awesomely smart, honest and "motivated" patient, who is free of unconscious processes, two-facedness and ulterior motive, just like the physician... For some reason, his disorder has not affected his ability to hear kind and supportive words. And both of them, motivated by mutual affection and the desire "to inform and to be informed", meet in the extraordinary space; they also have more than enough time to talk about everything. After all, let's ask ourselves: "Is that free choice really possible?"

It is a suitable time to recall the words from the epigraph: "...Securing agreement on general claims (like "respect human beings") is easy but securing agreement on the meaning of these claims is not". That is, the general principle "the patient has a right to be informed" is not (and cannot be) satisfactorily implemented in private manner.

And we're back to the fact that the existing form of IC explicitly or more often implicitly suggests that all people are the same ${ }^{6}$. In other words, psychological aspects of decision making (to accept/not to accept) are not taken into account by the law. That is why the diversity and complexity of the internal picture of the disease together with understanding the purpose of patient's visit to the doctor [10] are replaced by the process agreement. All the technological clarifications concerning the interaction between the parties ("delicately", "gradually", "amply", "in simple terms", etc.) appear to be the flirty smile of the Market towards humanism and good intentions.

"It is enough for the physician to one day become a medical practice's customer to experience firsthand the illusion of the declared medical "moral progress", as well as the pharisaical, hypocritical nature of requirements for the customer stated in the listed above declarations: "to have adequate (?NZ) knowledge" in order to "make an informed free choice". "Adequacy", "mindfulness", etc., are the fundamentally nonoperationalizible terms (either being non-verifiable, or being verifiable in theory through specific conventional long-term psychological research). And, if so, once spoken aloud these words immediately become mottos. In the contemporary medical education arrangement system there are no physicians having "adequate knowledge", to "make informed decisions" while acting as a patient, in case the issue goes beyond their narrow specialization, not to mention the non-physicians, and the fact that in an era of the Fourth Estate no decision could be called free. Freedom has been successfully substituted by mottos about Freedom" [12].

Makes you wonder if anybody knows this. Many physicians are well aware that the "free choice" is simply impossible. For example, by definition, as "life constrained in its freedom" ( $K$. Marx) can't possibly be free to choose. At their best, physicians and patients are left to rely on intuition, and in the worst case they are left to mimic sort of mutual agreement.

This looks especially cynical and prominent in case of obtaining the IC to mercy killing (euthanasia). For example, a 12-year-old adolescent (Netherlands) is expected to be aware of the meaning and consequences of the situation, and certain physician (usually psychiatrist) is thought to be able to ascertain this. Situation of IC in mentally disabled patients is no better [ibid.].

A few implicit self-deprecating assumptions can be discerned in the reform efforts of Russia, suffering from the national inferiority complex since ancient times: that society together with ethics always develop progressively; that the Western medicine is obviously by all accounts better than other kinds of medicine; that it is scary to have a reputation of retrograde and supporter of "undemocratic solutions", as well as of paternalism supporter, etc. With that attitude of the situation we are in danger of losing our autonomy.

\section{Conclusion}

First, the experimental procedure (for which the IC process was originally created) differs significantly from daily medical practice, whereas there has been no substantive change in IC. This is one of the reasons why a large number of physicians reject IC. Perhaps, the fundamentally different IC forms should be developed for different situations: for clinical trials (CT), for disorders (IC to intervention), for euthanasia ${ }^{7}$, etc.

Second, the IC Law "for every person" in used in Russian clinical practice, i.e. it is a part of the species survival strategy. There is no (and, perhaps, there cannot be any) satisfactory mechanism of the Law implementation under the individual survival strategy, i.e. the application of the Law to a certain individual.

Third, we have a reason to believe that nowadays the problem of IC in certain patient has no other solution than to remain the legal construct servicing the market economy. As such, this is reasonably necessary. We should treat declarations on freedom and desired voluntary bounds accordingly. We have to admit that the only truly free patient's choice is the choice of refusal to be informed and shifting the responsibility onto physician.

Fourth, it's quite possible that the future attempts at improving the IC Law would require getting back with "obsolete" values of classical medicine.

${ }^{6}$ «While understanding the psychological aspects $<\ldots>$ interests did not always coincide, i.e. have the same objects. That is why those, who try to prove the coincidence of interests on the basis of the human nature unity, fail to achieve the desired goals» [11] (p .466).

${ }^{7}$ Unfortunately, you can be sure that the issue of euthanasia legalization in Russia would be raised.... 


\section{References}

1. Symons $X$. Can we synthesise Christianity moral theology with secular bioethics? BioEdge, 2020. https://www.bioedge.org/ bioethics/can-we-synthesise-christianity-moral-theology-withsecular-bioethics/13629/.

2. Tishhenko PD. Zhizn' i vlast': bio-vlast' v sovremennyh strukturah vrachevanija, Zhurnal'nyj klub «Intelros» Biojetika i gumanitarnaja jekspertiza» №4, 2010. URL: http://www.intelros.ru/pdf/ Bioetika/4/03.pdf/ Russian.

3. Zorin NA. Krugovorot porokov, boleznej i dobrodetelej, Al'manah Centra issledovanij jekonomicheskoj kul'tury. Special'nyj vypusk "Jekonomika porokov i dobrodetelej". M., SPb.: Iz-vo Instituta Gajdara., 2016; 150-170 p. https://www.academia edu/37962771/ Russian

4. Cain R. How neoliberalism is damaging your mental health. 2018. https://theconversation.com/how-neoliberalism-is-damagingyour-mental-health-90565

5. Zorin NA. Bezgreshnye retransljatory Izhi ili mehanizmy perekladyvanija viny $v$ medicine, kak forma legitimizacii obmana. https://www.academia.edu/42222674/ Russian.

\section{Литература}

1. Symons $X$. Can we synthesise Christianity moral theology with secular bioethics? BioEdge, 2020. https://www.bioedge.org/ bioethics/can-we-synthesise-christianity-moral-theology-withsecular-bioethics/13629/.

2. Тищенко П. Д. Жизнь и власть: био-власть в современных структурах врачевания, Журнальный клуб "Интелрос» Биоэтика и гуманитарная экспертиза» 2010;4. URL: http:// www.intelros.ru/pdf/Bioetika/4/03.pdf/.

3. Зорин Н. А. Круговорот пороков, болезней и добродетелей, Альманах Центра исследований экономической культуры. Специальный выпуск "Экономика пороков и добродетелей". М., СПб.: Из-во Института Гайдара., 2016; 150-170 c. https:// www.academia.edu/37962771/

4. Cain R. How neoliberalism is damaging your mental health. 2018 . https://theconversation.com/how-neoliberalism-is-damagingyour-mental-health-90565.

5. Зорин Н. А. Безгрешные ретрансляторы лжи или механизмы перекладывания вины в медицине, как форма легитимизации обмана. https://www.academia.edu/42222674/.
6. Vlasov $\mathrm{W}$. Informirovanie pacienta i ego soglasie na lechenie. http://osdm.org/blog/2020/08/22/informirovanie-pacienta-i-egosoglasie-na-lechenie/\#more-16568/ Russian.

7. Forum Vrachi RF. Podborka statej o kljatve Gippokrata. https:// vrachirf.ru/search?query/ Russian.

8. King $\mathrm{H}$. Hippocrates didn't write the oath, so why is he the father of medicine? The Conversation 2014. https://theconversation. $\mathrm{com} /$ hippocrates-didnt-write-the-oath-so-why-is-he-the-fatherof-medicine-32334.

9. Dawes M, Summerskill W, Glasziou P. et al. Sicily statement on evidence-based practice. BMC Med Educ 2005;5: 1. https:// doi.org/10.1186/1472-6920-5-1 https://bmcmededuc. biomedcentral.com/articles/10.1186/1472-6920-5-1/.

10. Zorin NA. Zachem bol'noj prihodit k vrachu? Glavnyj vrach, 2002; (2): 62-65. https://www.academia.edu/41037041/ Russian.

11. Ossovskaja M. Rycar' i burzhua: Issled. po istorii morali. Gusejnov AA. redaktor. M.: Progress, 1987; 528 p. Russian.

12. Zorin NA. Ubej menja nezhno ili lechenie smert'ju (ob jevtanazii) Chast' I. Zhurnal im. P.B.Gannushkina. 2021; (23): 34-44. Russian.

6. Власов В. В. Информирование пациента и его согласие на лечение. http://osdm.org/blog/2020/08/22/informirovaniepacienta-i-ego-soglasie-na-lechenie/\#more-16568/.

7. Форум Врачи РФ. Подборка статей о клятве Гиппократа https://vrachirf.ru/search?query/.

8. King H. Hippocrates didn't write the oath, so why is he the father of medicine? The Conversation 2014. https://theconversation. com/hippocrates-didnt-write-the-oath-so-why-is-he-the-fatherof-medicine-32334.

9. Dawes M., Summerskill W., Glasziou P. et al. Sicily statement on evidence-based practice. BMC Med Educ 2005:5: 1. https://doi.org/10.1186/1472-6920-5-1 https://bmcmededuc. biomedcentral.com/articles/10.1186/1472-6920-5-1/.

10. Зорин Н.А. Зачем больной приходит к врачу? Главный врач, 2002; (2): 62-65. https://www.academia.edu/41037041/.

11. Оссовская М. Рыцарь и буржуа: Исслед. по истории морали. Гусейнов А. А. редактор. М.: Прогресс, 1987; 528 с.

12. Зорин Н. А. Убей меня нежно или лечение смертью (об эвтаназии) Часть І. Журнал им. П.Б.Ганнушкина. 2021; (23): 34-44. 